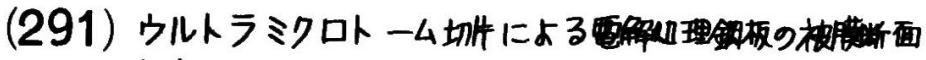

\title{
1. 䋖言
}

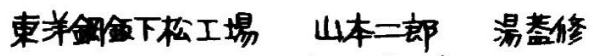 ○野村差一郎}

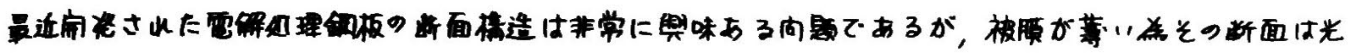

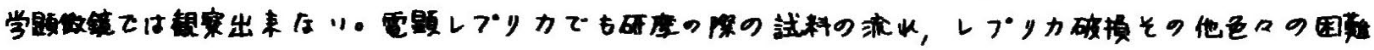
点がある。

そこで生物，医学方面で事ら使用されているウルトラミクロトームに上る场断法応用してみた。方の

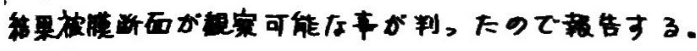

2. 央社苰

\section{2-1. 包埋用武料作成}

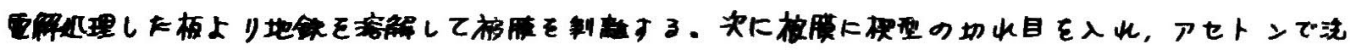
将する。

\section{2-2. 包埋}

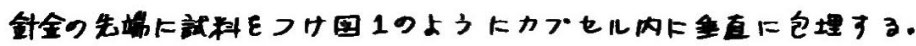

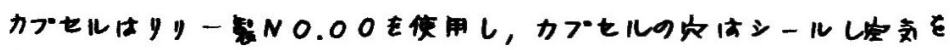

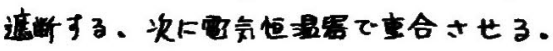

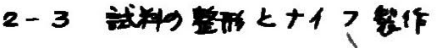

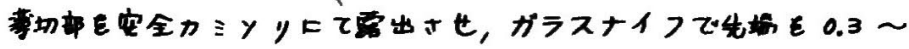

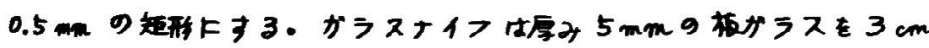

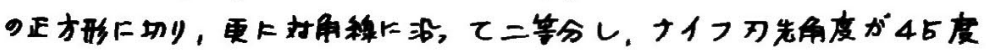

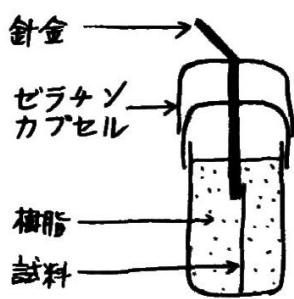

园1包埋方法 に泣るよにした。

\section{2-4 包堤用箱脚}

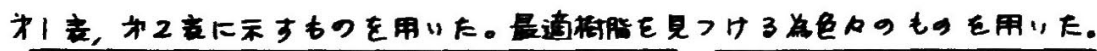

\begin{tabular}{|c|c|c|c|}
\hline 正ブキルメタクりレート (CC) & 16 & 12 & 8 \\
\hline I4N.x99)L-1 (*) & 4 & 8 & 12 \\
\hline 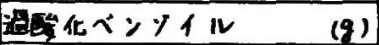 & 0.2 & 0.2 & 0.2 \\
\hline
\end{tabular}

直合件 $40 \sim 45^{\circ} \mathrm{C} \times 30 \sim 40$ 暗问 於表メタワリル相脂

\begin{tabular}{|c|c|c|c|}
\hline$A$ & Iボン8|2(cc) & 62 & 湜合比 \\
\hline & $D D S A$ & 100 & $A 10+B 10+$ \\
\hline$B$ & Iボン $812(0)$ & 100 & DM P-30 0.4 \\
\hline & $M N A$ & 89 & \\
\hline
\end{tabular}

冝合条件 $40^{\circ} \mathrm{C} \times 15$ 明间 $+60^{\circ} \mathrm{C} 15$ 明间

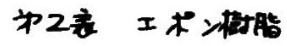

\section{2ー5 ウルトラミクロトームによる切削}

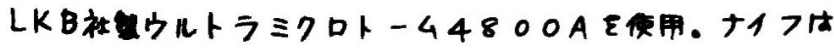
45度のザラスナイフとダイヤモンドナイフ 便用した。ボート

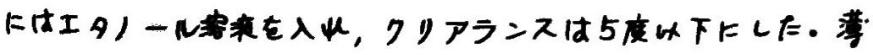

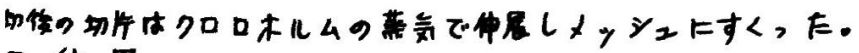
3. 結果

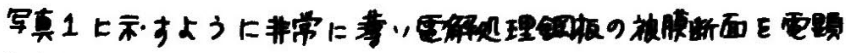

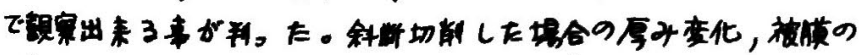

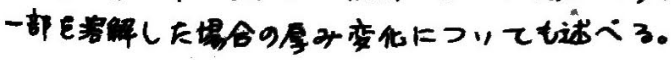

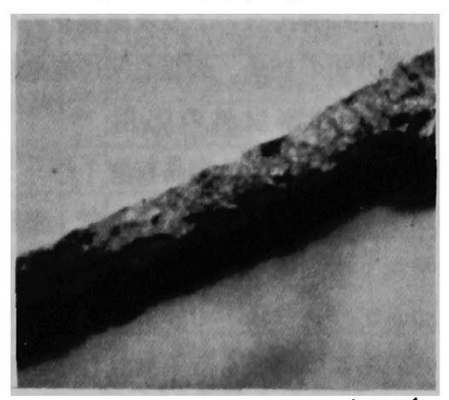

军真1 被㬴の西 


\section{八蛙製鉄所技術研究所村上福義副易 萣 \\ ○神田光雄 工博一戸正良}

1. 籍 言

光学影鏡とテレビションを組合せた基を用いて介在物その他の面皘率や粒度分布などを測定した。

2. 测定の原理

柿置は写真1亿示した上9に光学影微 鉑とテレビションを組合せをるのて、検 波器や積算計などが内藏されている。目 的とナる器相（例えば介在物）をテレビ ションのスクリーン上に現出せしめ、走 奋線て走茼ナると異相の種類に上つて高 さの定主るハルスが発生ナる。哄相の面 皘率はパルス長さの線和と走枯線全長と の比として計器にあらわれる。粒度測定の. 場合は粒界と走查線の交点て生な゙るパスス の数を利用さる。

3. 測定精度の検討

面積率既知の人工試料を用的て測定精度 を検討しを結果を図 2 亿示した。ハーライト 面皘率などの上らに面棲率が数\%以上の場 合は充分実用性はある。介在物の上のに通 常 $0.3 \%$ 以下の面橡率を問題と士る場合㤌

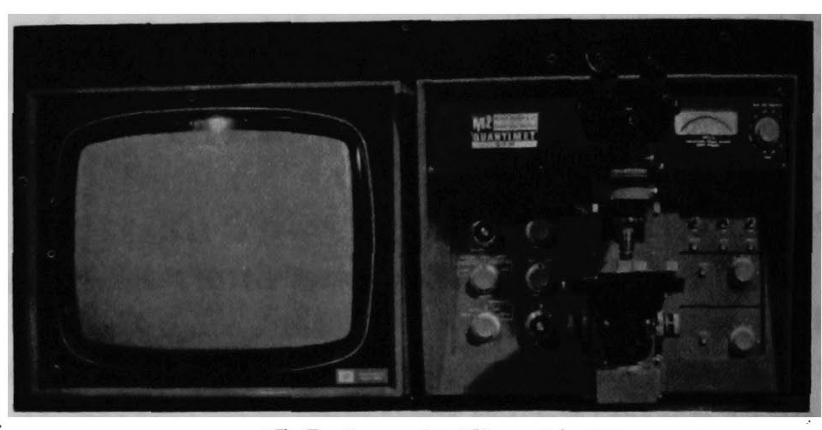

字兵 1 琵需の外知

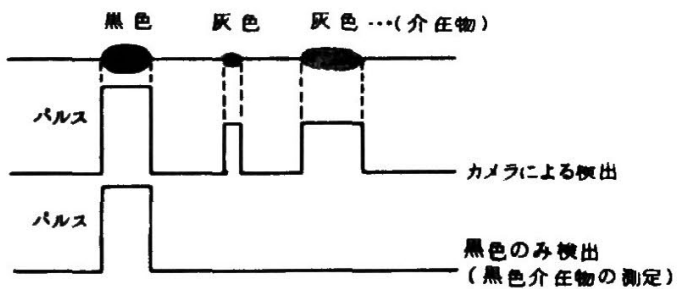

因 1 测定○原理 介在物の面棈率、大きさ、種嵲、要求精度 などに上つて対物鏡の倍率や視野数を適当に定める必要がある。

4. 介在物測定結果の一例

表 $1 \mathrm{KS}$ 快削の硫化物刢定結果を示した。則足者 $\mathrm{A}$ 凤平均 値が他の溂定者に比㜞して若干高的。この上のな测定者に上る 俱差は(イビントの合せ万、句スクリーン上てのコントラストの 与え万，に起扔のて測定者間て調整しておく必典がある。 表 1の結果は特にての上らな調整を行なわないて得たののてあ ろが分散分析の結果、刷定者間に有意差がるいととがかかつた。

5. 介在物面棲率以外の底用 介在物の粒度分布、結昆粒度，六ーライ

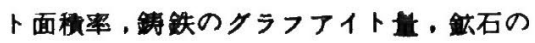
僄元状洗，耐火物户蛙結金の粉末粒度，な どとつレてはスライドで説明する。

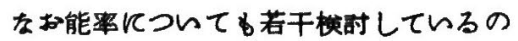
でライドで説明ナる。

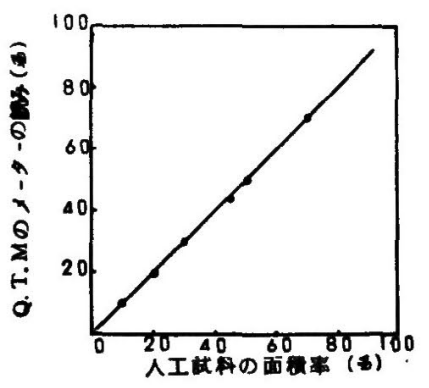

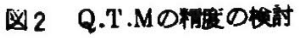

表 1 介在物面積率湘定結果（ $\mathrm{s}$ 快削鈳）

\begin{tabular}{|c|c|c|c|c|c|c|}
\hline & \multicolumn{5}{|c|}{ 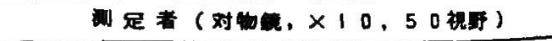 } \\
\hline & & $\mathbf{A}_{\mathbf{1}}$ & A. & A. & A. & Ai $^{2}$ \\
\hline \multirow{2}{*}{$\begin{array}{c}\text { 制足回 } \\
10 \text { 回 }\end{array}$} & $\bar{\mu}$ & 03481 & 03671 & 03484 & 03514 & 03551 \\
\hline & $\sigma$ & 0.0324 & 0.0147 & 0.0367 & 0.0318 & 00275 \\
\hline \multicolumn{2}{|c|}{ 分教分析 } & \multicolumn{5}{|c|}{$F_{0}: 1.60<F(4.45 .0 .05): 2.58$} \\
\hline
\end{tabular}


(293) ガスクロストグラフによろ商妒ガス及びコークス炉カス全成分の分析

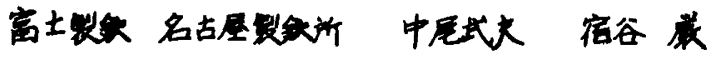
・田上薮.

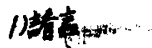

カスフロマトグラフによろ高妒历ス・コークス炉元スの成分 $\left(\mathrm{H}_{2} \cdot \mathrm{O}_{2} \cdot \mathrm{N}_{2} \cdot \mathrm{CO} \cdot \mathrm{CH}_{4} \cdot \mathrm{C}_{2} \mathrm{H}_{4} \cdot \mathrm{CO}_{2} \cdot \mathrm{C}_{2} \mathrm{H}_{4}\right)$ 分

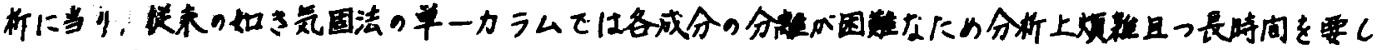

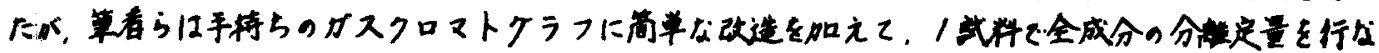

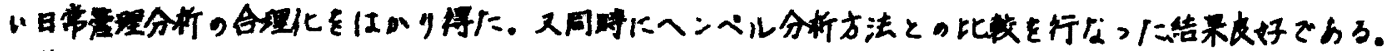

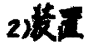

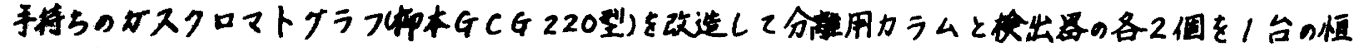

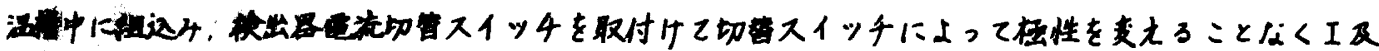

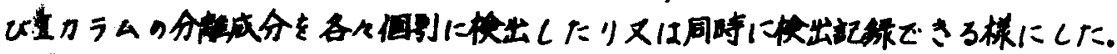

3)䉼方法

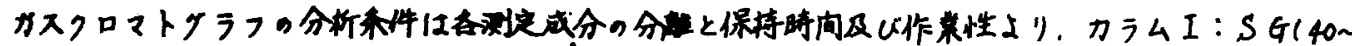

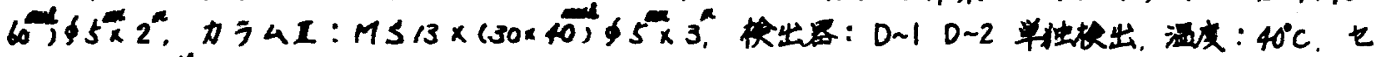

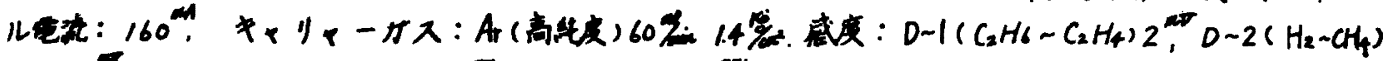

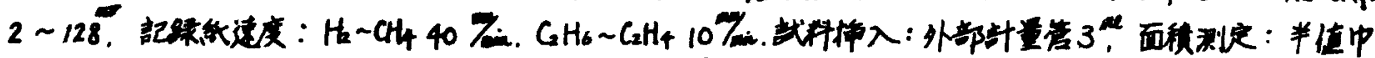

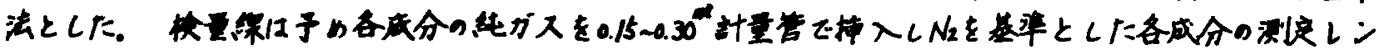

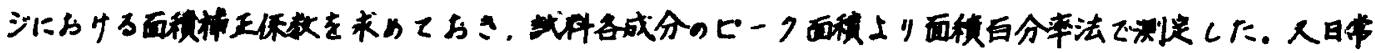

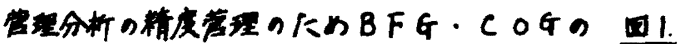

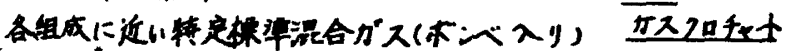

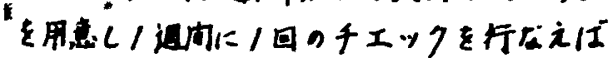
良い。四ににガスフロマトグラフチャート。 一/例を示才。 (4)分析结果

BFGRU゙COGの 组成儿近以CT特是保

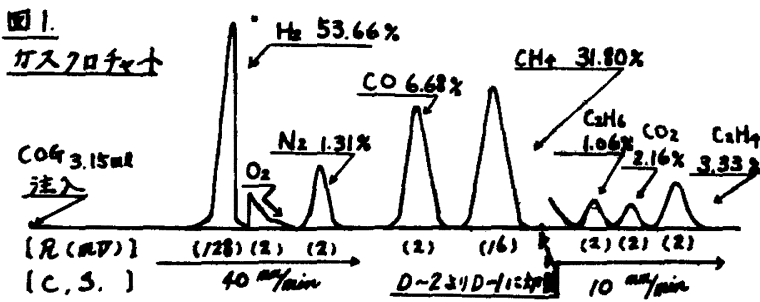

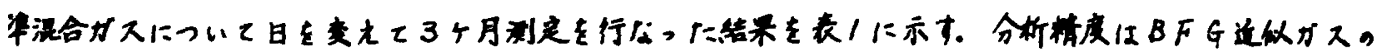

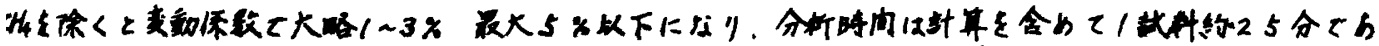

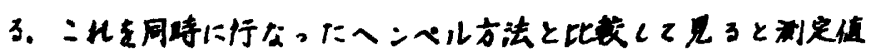

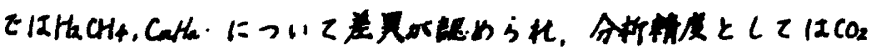

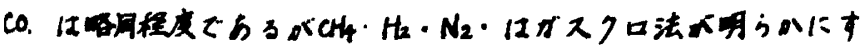

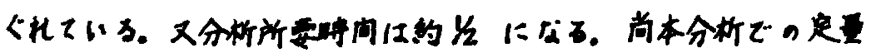

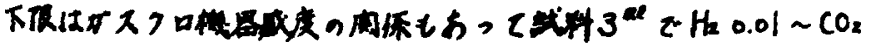

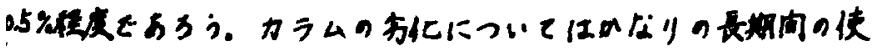

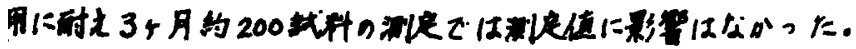
5)结官

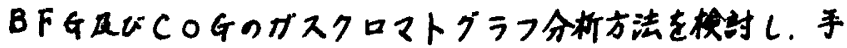
表1分析林度

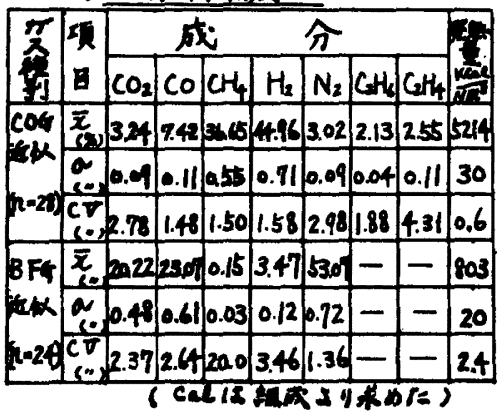

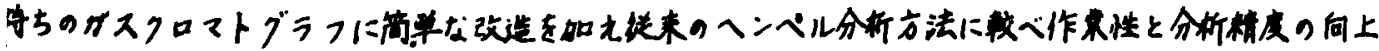

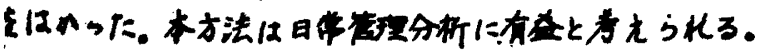


S 638

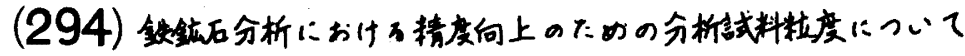

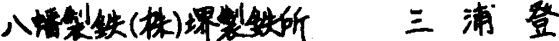 \\ ○大㮛孝}

1. いシさつ.

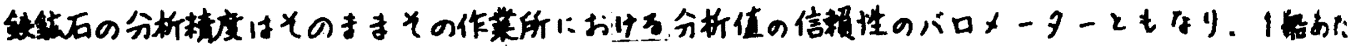

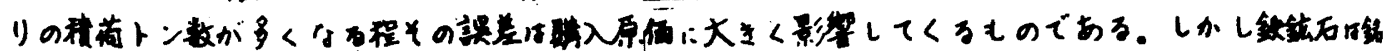

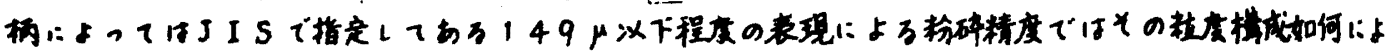

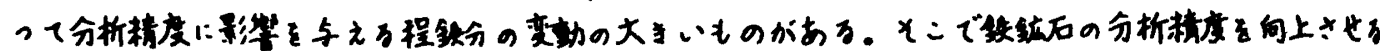

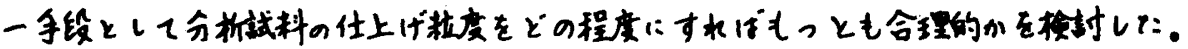

2. 实跙.

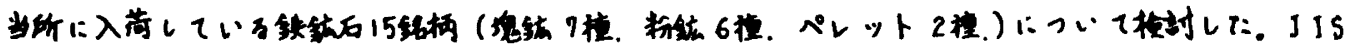

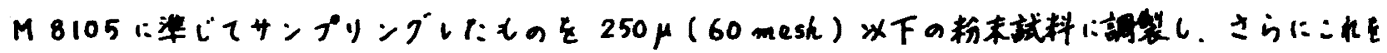

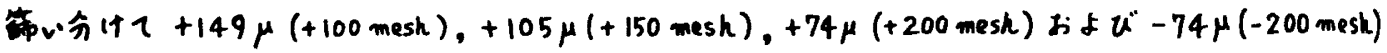
94 段䧄: 分けt:。

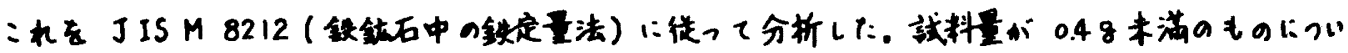
ては全是是用いて分析した：

3. 考察。

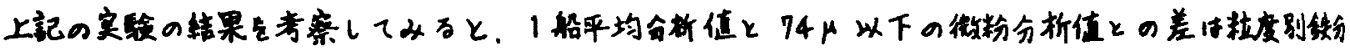

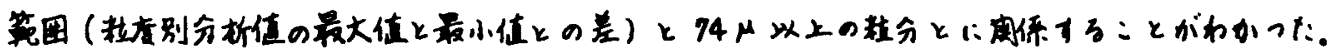

このンとから $74 \mu$ 以上の粒度の湿入铁客百分率( 8 )は

つ点の式でホのされろ。

$$
\delta=10^{4} \mathrm{D} / \mathrm{C} \cdot \mathrm{d}
$$

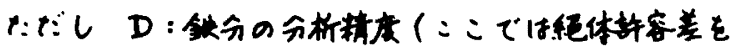

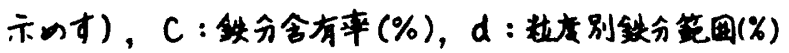

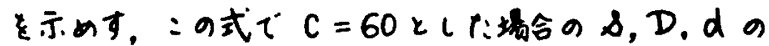
用係を四1に示のす。

4. 結部

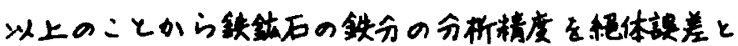
して $0.2 \%$ におさのるてのには代料の仕上り粒度分布を

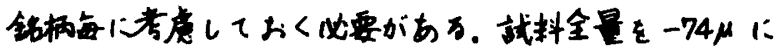

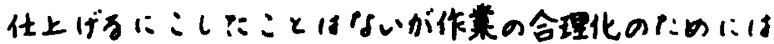

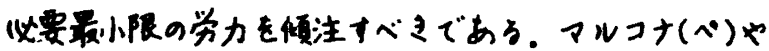

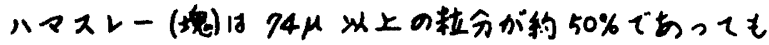

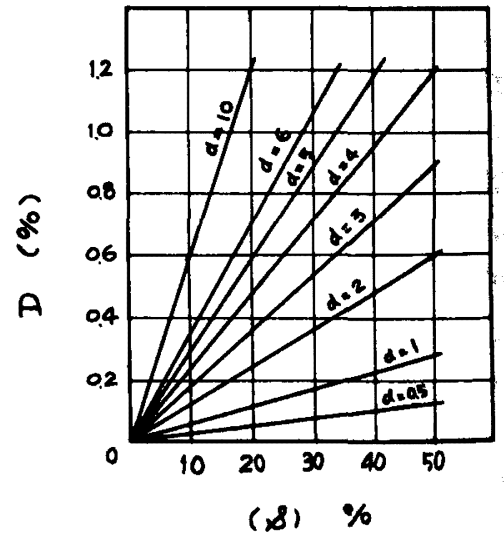

回1仕上げ粒度火分析精度。 よいか～ホンつン(粉)，ワイメラ(堍），E・マウンテン

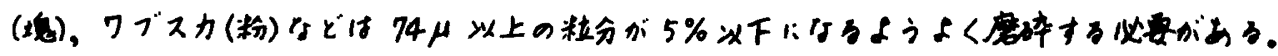




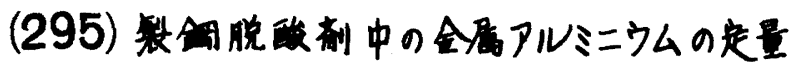

1. 传言

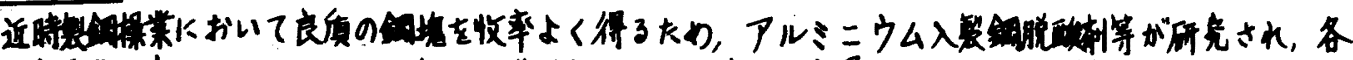

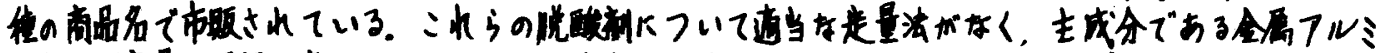

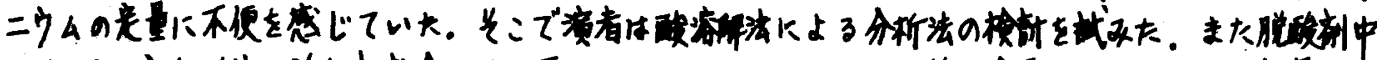

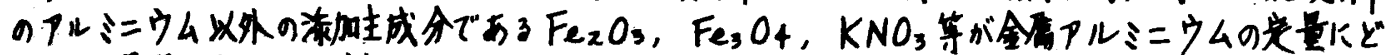

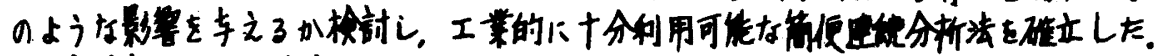

2. 整方法およで考察

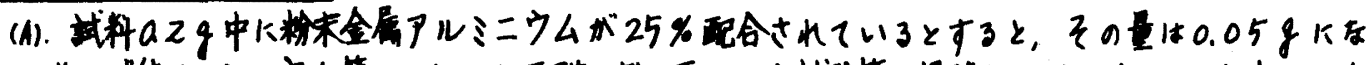

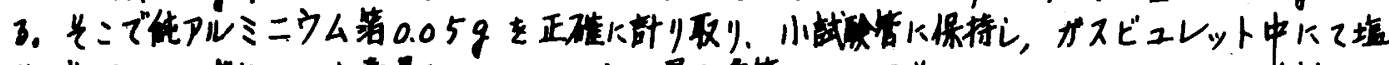

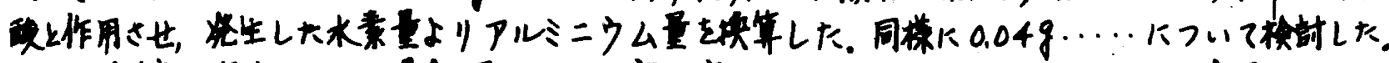

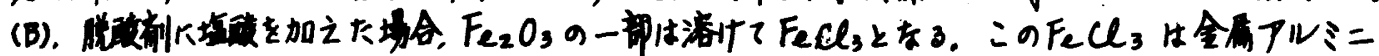

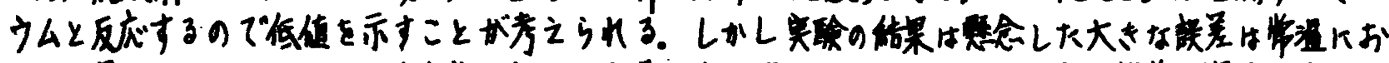

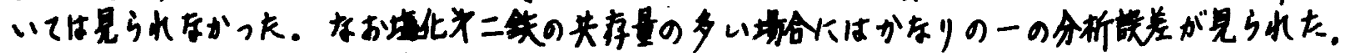

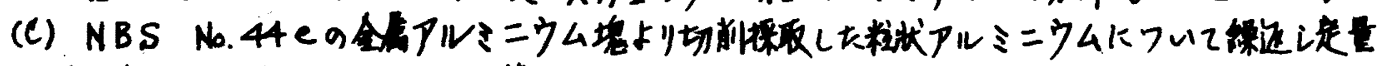

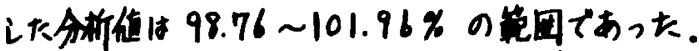

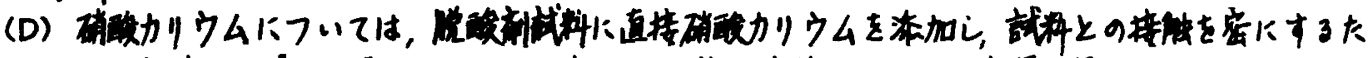

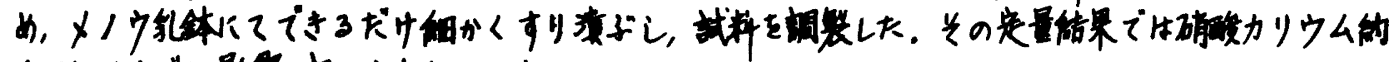

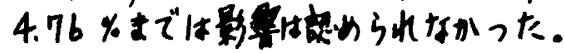

3. 牙析方法

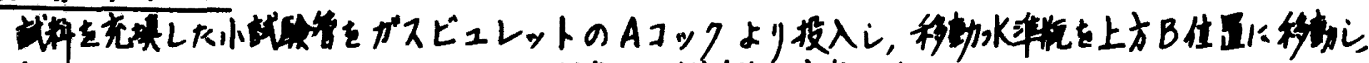

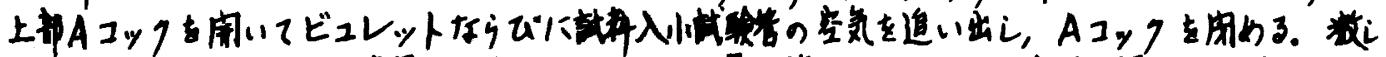

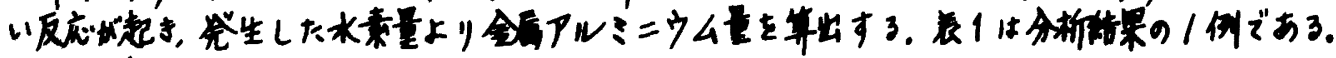

4. 传

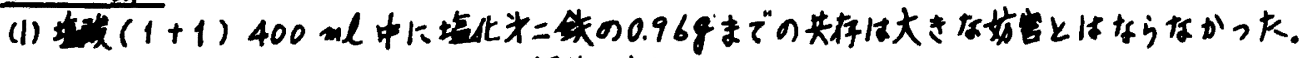

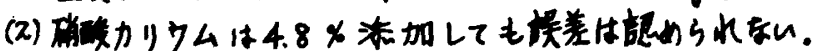

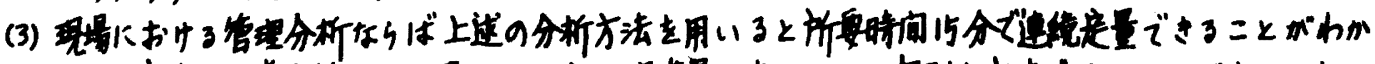

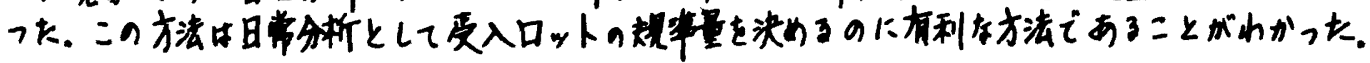

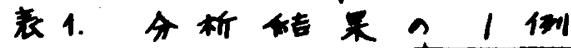

\begin{tabular}{|c|c|c|c|c|c|c|c|}
\hline ing & Ele & 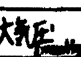 & $A\left(x_{2}=2(g)\right.$ & 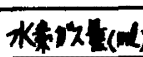 & 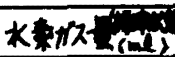 & $A l \&\left(\frac{1}{x} \times 1+1\right)$ & $\left.\right|^{*}$ \\
\hline 1 & 22 & 762 & 0.050 & 67.0 & 62.2 & 99.91 & Al toly y \\
\hline 19 & 20 & 762 & 0.020 & 26.6 & 24.87 & 99.89 & " \\
\hline 22 & 22 & 766 & 0.050 & 66.4 & 61.89 & 99.41 & \\
\hline 4 & 25 & 770 & 0.050 & 65.2 & 60.49 & 97.14 & \\
\hline 45 & 16 & 765.5 & $0.20($ titan) & 38.8 & 36.9 & 14.82 & \\
\hline 64 & 25 & 770 & $0.20()$. & 38.2 & 35.2 & 14.14 & \\
\hline 75 & 24 & 764 & $0.191(\cdot)$ & 37.8 & 34.89 & 14.67 & 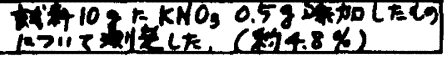 \\
\hline
\end{tabular}


S 640

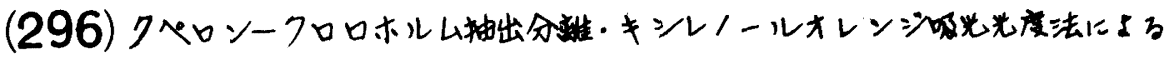
タンブスラン用中、ジルコニシム是星法

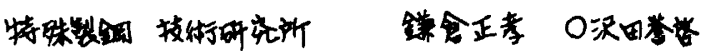

\section{1. 絏言}

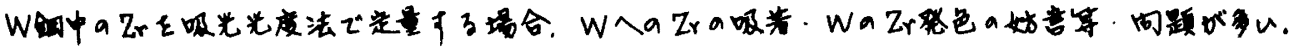

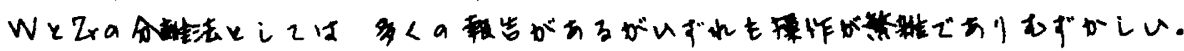

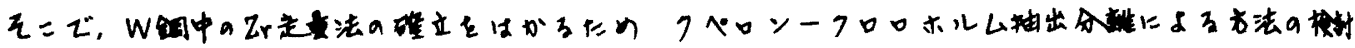

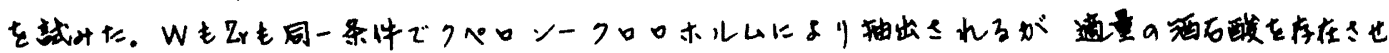

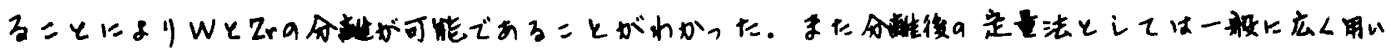

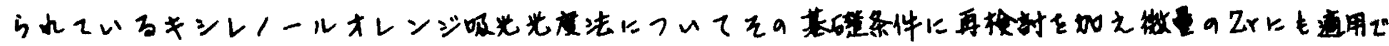
芷ンにレた。

\section{2. 分称作}

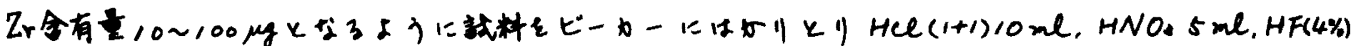

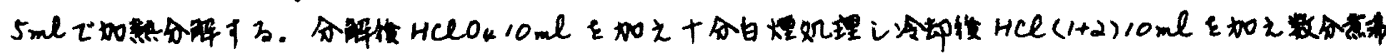

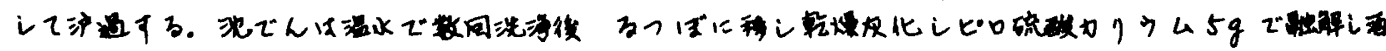

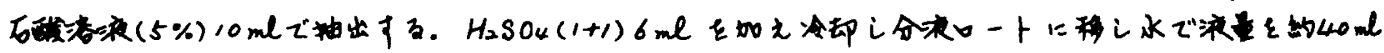

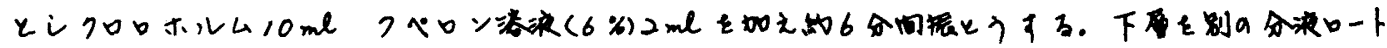

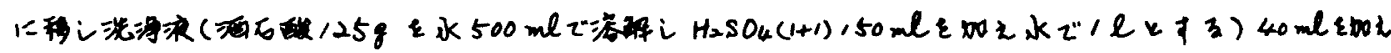

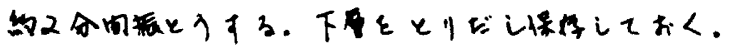

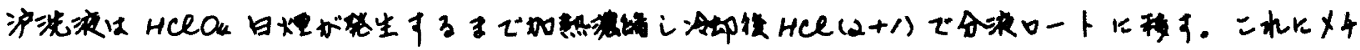

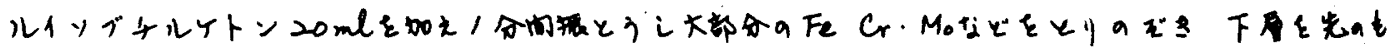
のとカむせる。

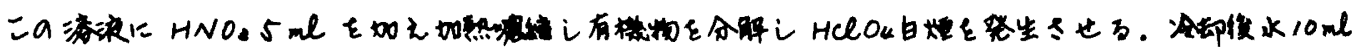

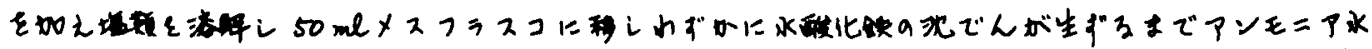

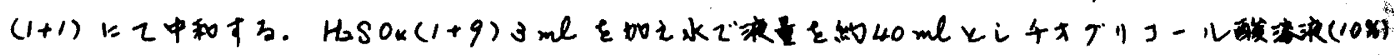

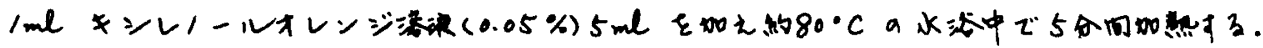

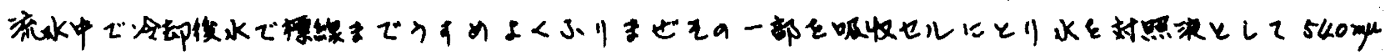

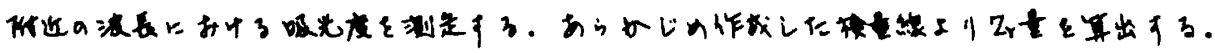

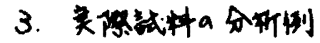

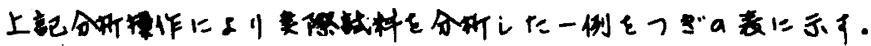

表1. 实绦试料の分新例

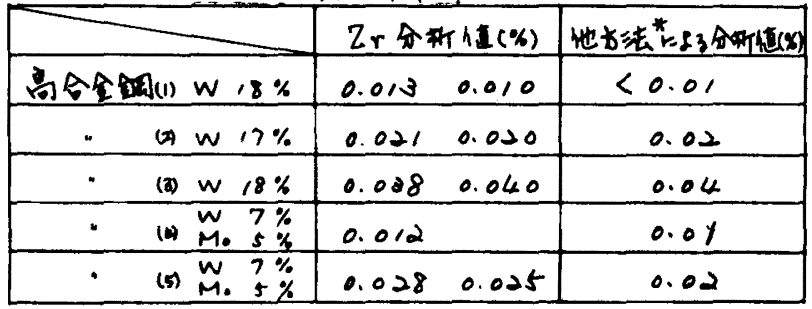

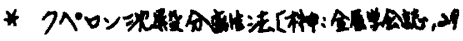
(4965)/5/ /58] $1=832$ r A 
（297）原子吸光泛による鉄筒中微量カルシンムの定量

\section{日立金属安来工場。市川景筑}

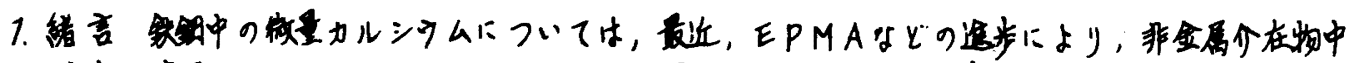

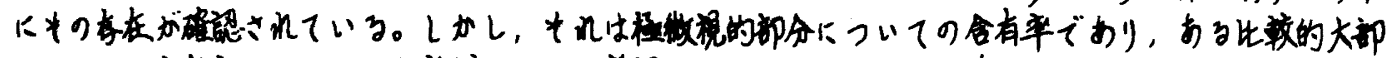

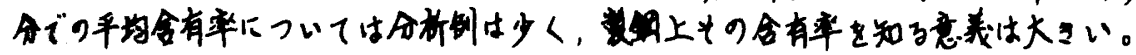

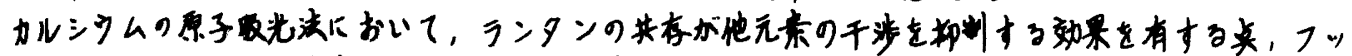

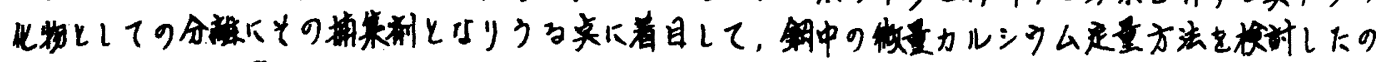

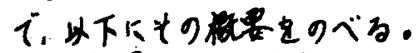

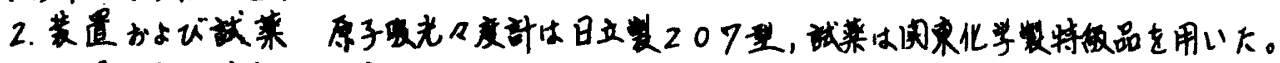

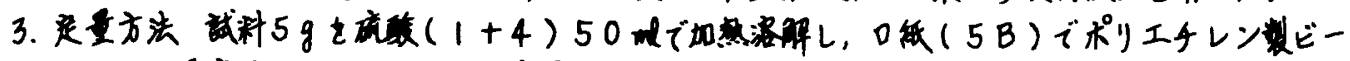

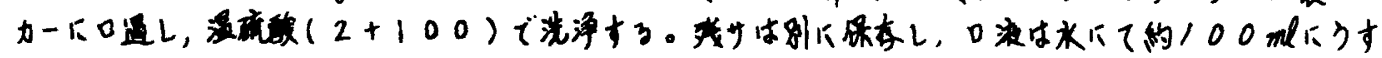

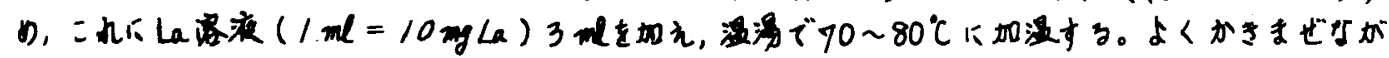

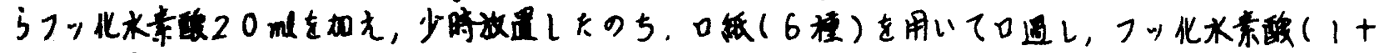

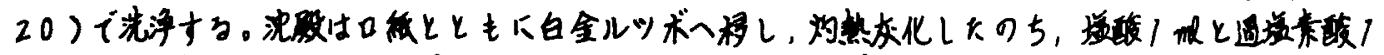

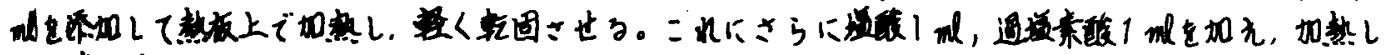

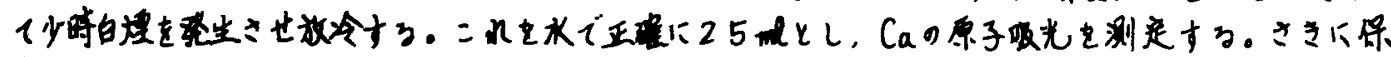

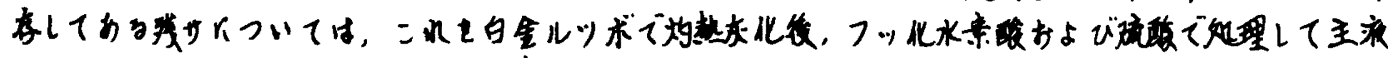

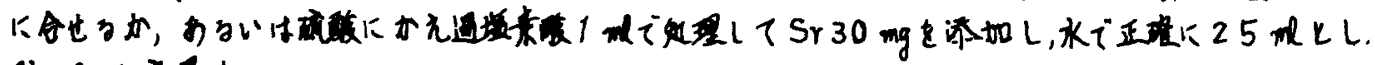

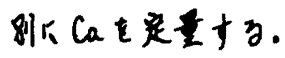

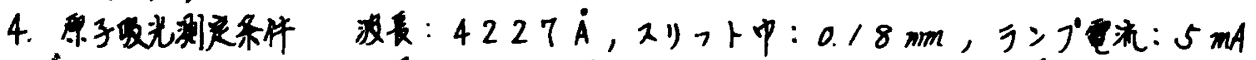

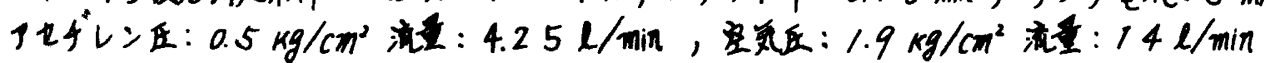

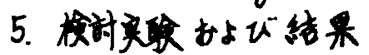

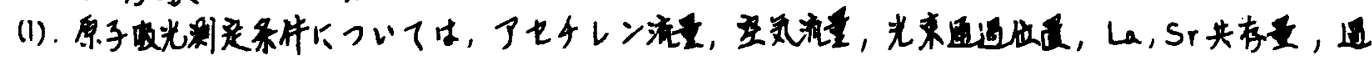

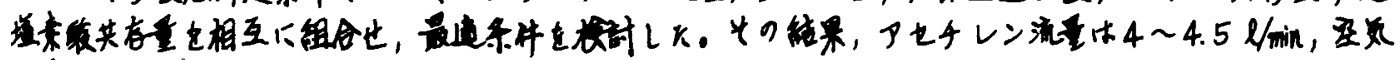

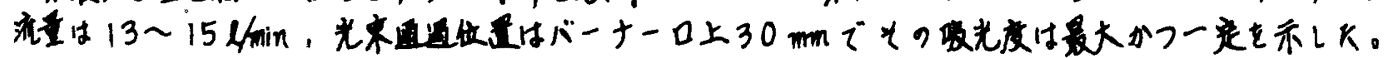

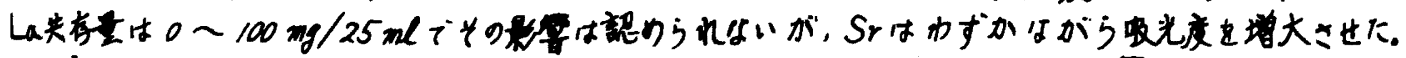

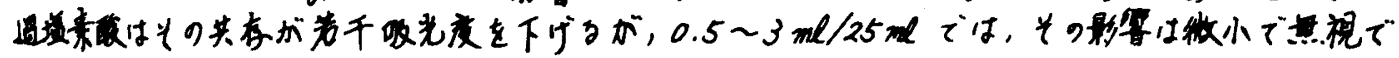
ว3.

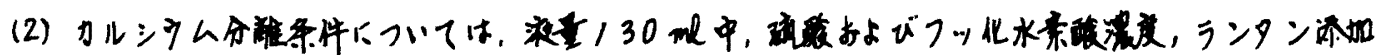

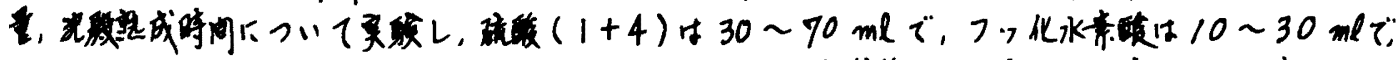

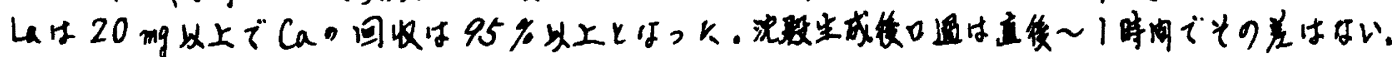

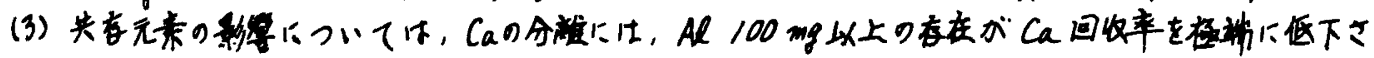

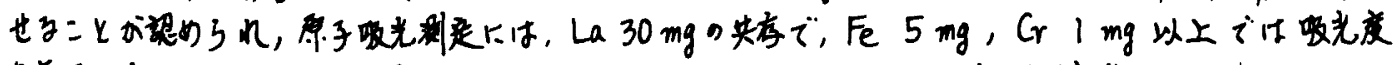

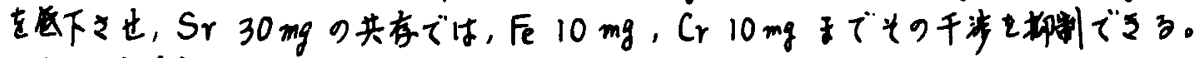

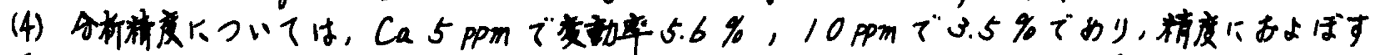

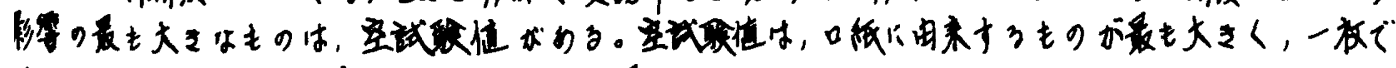

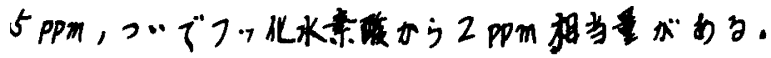




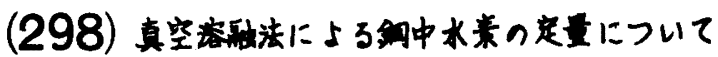

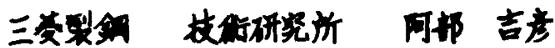

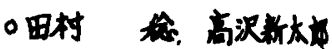

\section{1. 楮言}

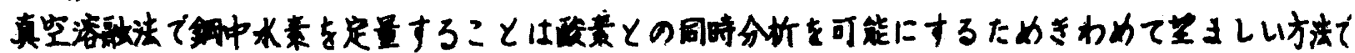

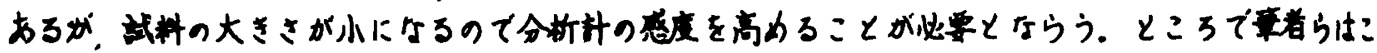

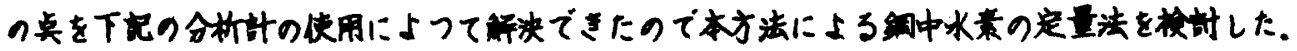

\section{2. 实政才法}

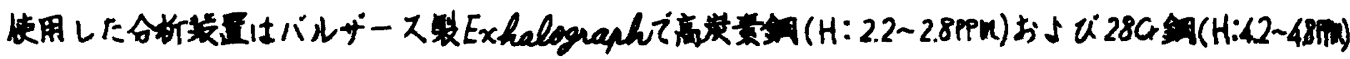

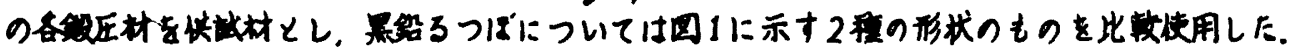

\section{3. 结果女落客}

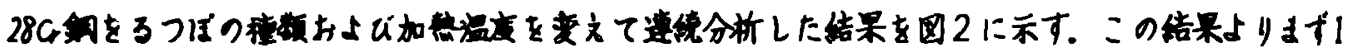

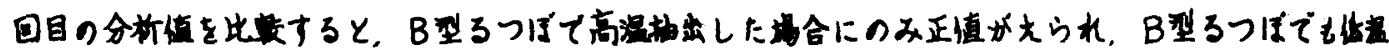

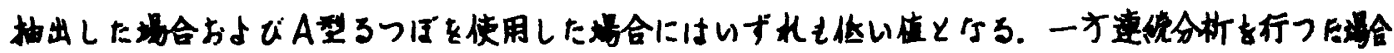

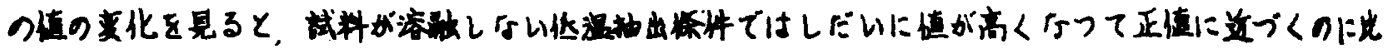

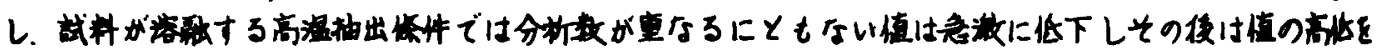

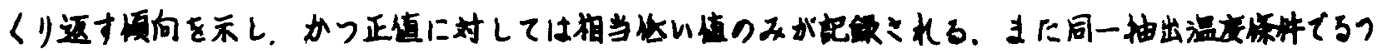

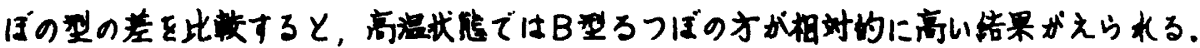

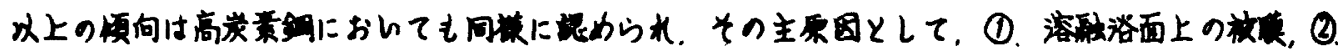

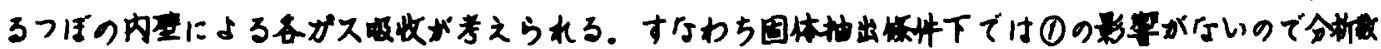

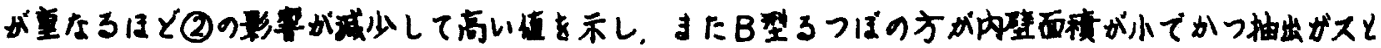

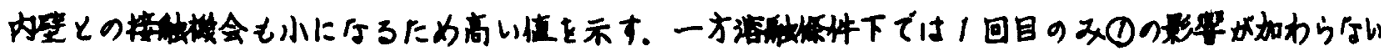

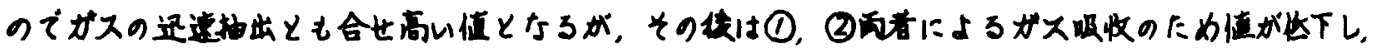

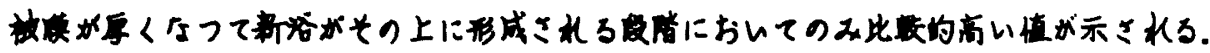

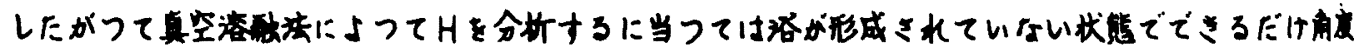

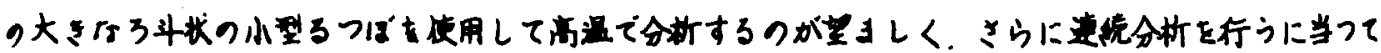

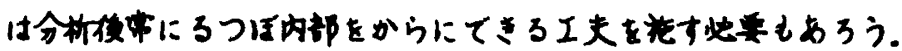

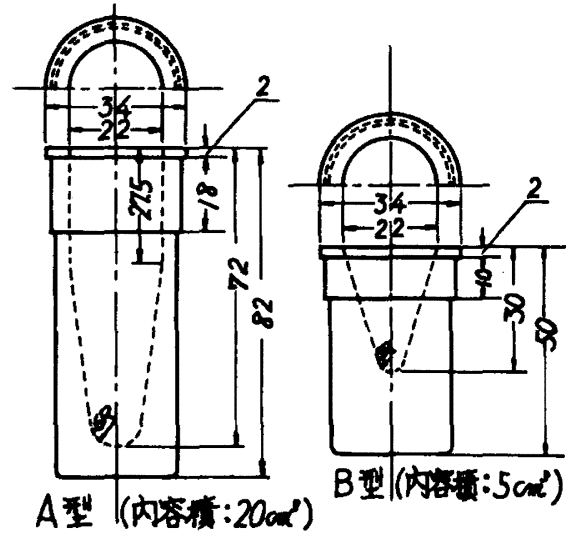

因1。快坻用了つ玨

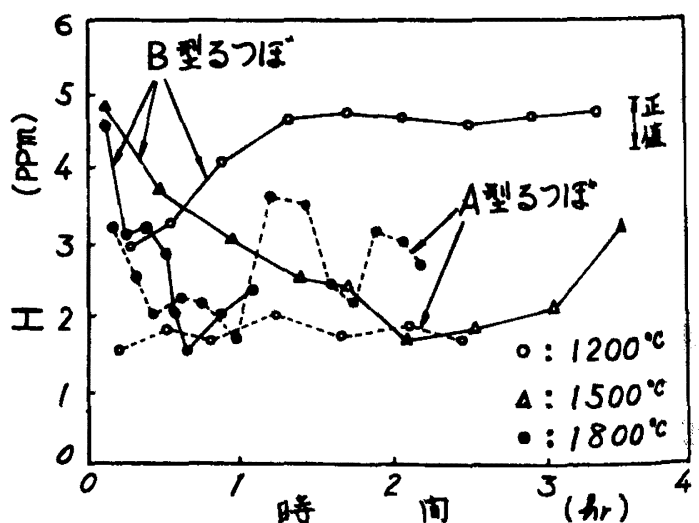

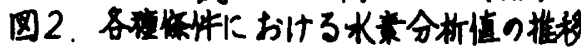


(299) X M A 定暴載正計算人の㫣子計算機の利用

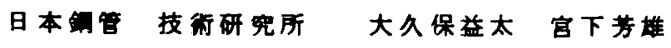

菲井明。德永实已

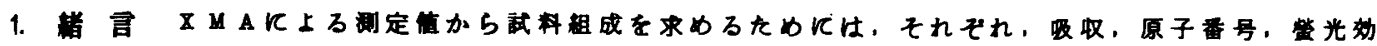

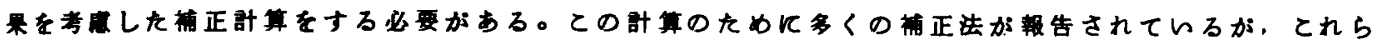

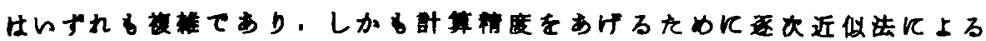

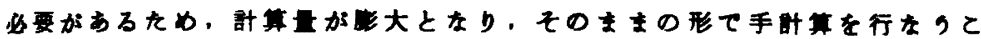

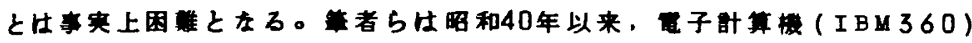

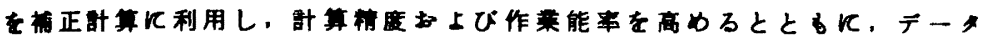
○整理および保管などにる役立たせてきた。

2.プロクラムの内宫者らが用いている計算プロクラムのフロー

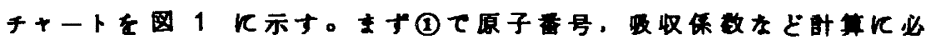

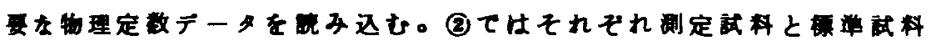

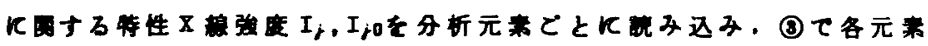

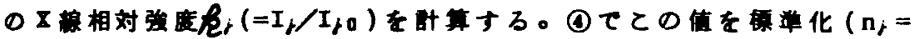

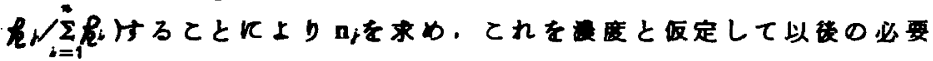

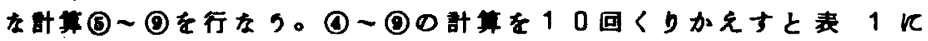

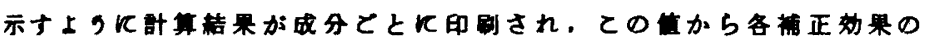
寄与する㲅合をる知るととがてをる。また計算結果が取れんする上の 士を $\mathrm{Al}_{2} \mathrm{O}_{2}-\mathrm{\theta 1}_{1} \mathrm{O}_{2}-\mathrm{MnO}-\mathrm{F} \theta \mathrm{O}$ 来介在物について示した表 2 上り，10回

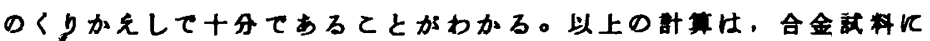

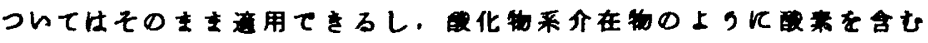

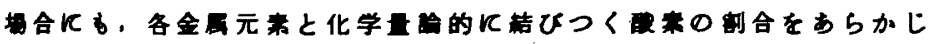

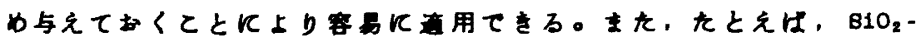

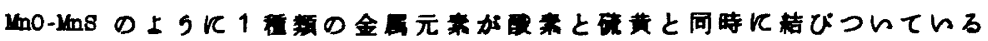

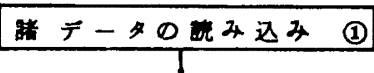
分析データの䗷み込み (2. 相 対 强

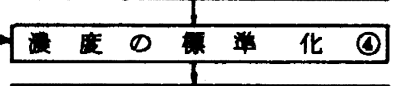

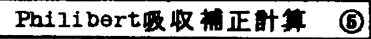

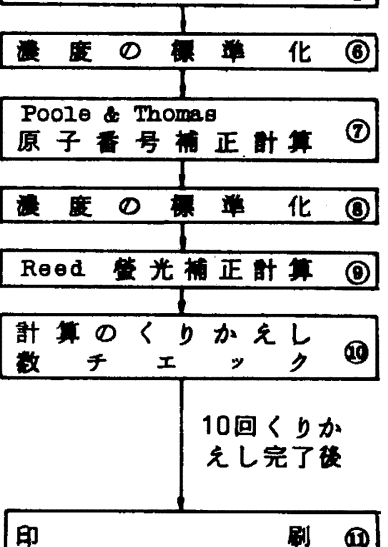

図 1 フローチャート

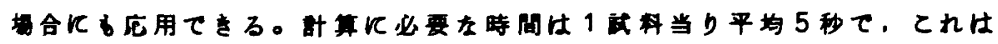

計算機借用料金として 35 円飞相当する。

表 1 フゥトブットテータ

ANALYBIS NO. SAMPLE NO.

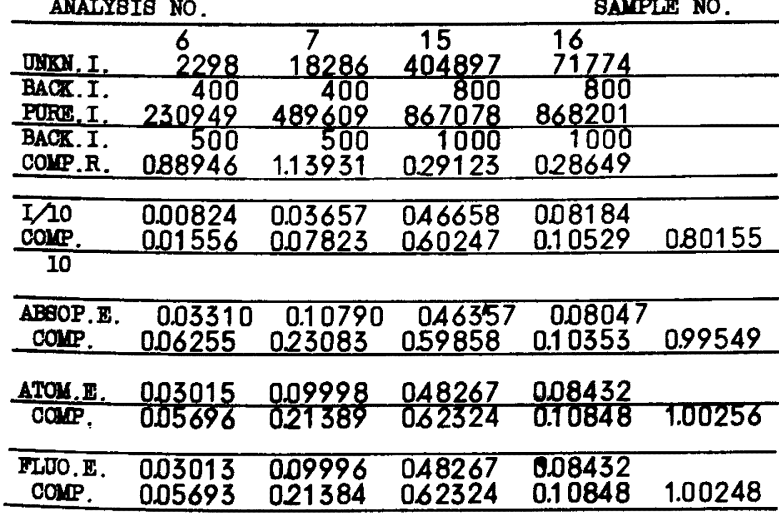

表 2 収九んの上っす

\begin{tabular}{|c|c|c|c|c|c|}
\hline くりかえし & $\mathrm{Al}_{2} \mathrm{O}_{3}$ & $\mathrm{S1O}_{2}$ & Mno & $\mathrm{FeO}$ & ㅂt \\
\hline 相対强 度 & 0.119 & 0.161 & 0.204 & 0.012 & 0.496 \\
\hline 1 & 0.367 & 0.475 & 0.233 & & 1.088 \\
\hline 2 & 0.292 & 0.456 & 0.234 & 0.013 & 0.995 \\
\hline 3 & 0.301 & 0.442 & 0.234 & 0.013 & 0.990 \\
\hline 4 & 0.300 & 0.448 & 0.234 & 0.013 & 0.995 \\
\hline 5 & 0.300 & 0.446 & 0.234 & 0.013 & 0.993 \\
\hline 6 & 0.300 & 0.446 & 0.234 & 0.013 & 0.993 \\
\hline 7 & 0.300 & 0.446 & 0.234 & 0.013 & 0.993 \\
\hline 8 & 0.300 & 0.446 & 0.234 & 0.013 & 0.993 \\
\hline 9 & 0.300 & 0.446 & 0.234 & 0.013 & 0.993 \\
\hline 10 & 0.300 & 0.446 & 0.234 & 0.013 & 0.993 \\
\hline
\end{tabular}




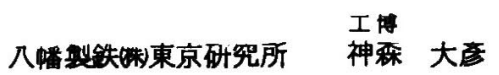 \\ O佐々木 稳、浜田 広缡}

試料スラブ材中の酸化物采介在物を分類してそれぞれ組成を决める目的から、大型介在物のいくつかを買び出 してX線マイクロアナライザーて分析した。

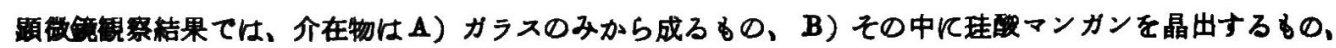

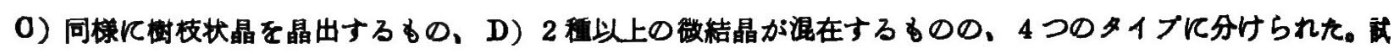

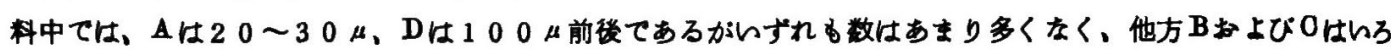
いろな大さてしかる多数見出された。

X線マイクロアナライザーに上ろ分析結果の数例を表1飞示した。こてては、均一相を狙って分析するととを 目的として、薄片 表 1 試料銅材中の代表的大型介在物の分析結果

試料(厚さ 12 $13 \mu$ )を使って ある。Aてはよん 定量値が得られて レろが、0は析出 している微細な樹 枝状晶と金属鉄の

\begin{tabular}{|c|c|c|c|c|c|c|c|c|c|c|}
\hline 記昂 & 晶出相 & 分析個所 & $\mathrm{MnO}$ & $\mathrm{CaO}$ & $\mathrm{MgO}$ & $\mathrm{Or} 2 \mathrm{O}_{3}$ & $\mathrm{Ti} 2 \mathrm{O}_{3}$ & $\mathrm{Al}_{2} \mathrm{O}_{3}$ & $\mathrm{BiO}_{2}$ & 合計 \\
\hline $\mathbf{A}$ & & カ $5 x$ & 12 & 30 & 4.0 & 0.9 & 0.7 & 15 & 33 & 96 \\
\hline 0 & 澍枝状晶 & $\pi$ & 30 & 3.4 & - & 6.5 & 1.6 & 17 & 34 & 93 \\
\hline \multirow{2}{*}{$D_{-1}$} & \multirow{2}{*}{$\begin{array}{l}\text { 徽結晶 } \\
\text { 混在相 }\end{array}$} & 徽粒磁集部 & 42 & 0.7 & - & 12 & 0.4 & - & 35 & 90 \\
\hline & & 同 上* & 42 & 0.6 & - & 11 & 0.4 & - & 33 & 87 \\
\hline \multirow{2}{*}{ D-2 } & \multirow{2}{*}{$\begin{array}{l}\text { 微結晶 } \\
\text { 混在相 }\end{array}$} & \multirow{2}{*}{$\begin{array}{l}\text { 砤粒提集部 } \\
\text { 同 上* }\end{array}$} & 45 & 0.8 & - & 11 & 0.4 & 1.0 & 31 & 89 \\
\hline & & & 46 & 0.7 & - & 12 & 0.4 & 0.7 & 31 & 91 \\
\hline
\end{tabular}
*印住 sample scanning methed К上る

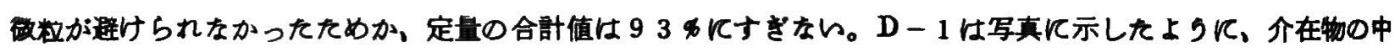

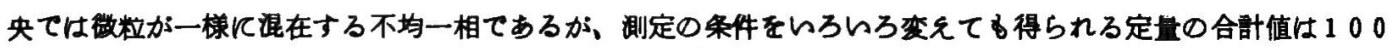
カ上りかなり低く、不均一相は正しく定量分析てきならてとが示されている。

介在物中の晶出相については、Bタイブにある进酸マンカンはX線マイクロフナライザーに上る定性分析と直 交ニコル下における光学的性貿の観察から rhodonite、( $\mathrm{MnO} .0 \mathrm{a}) \mathrm{O} . \mathrm{BiO} 2$ と判定され、0タイプの中の 枝状晶は光学等方性の透明結晶て $\mathrm{Mn} と \mathrm{Or}$ を多く含むととから $\alpha-\mathrm{Mn}_{2} \mathrm{O}_{3}$ の $\mathrm{Mn}$ の一部を Or が置換したるの と考えられた。Dタイブは rhodoniteと $(\mathrm{MnU}, \mathrm{Or}){ }_{2} \mathrm{O}$ 3がおるな結晶相てある。

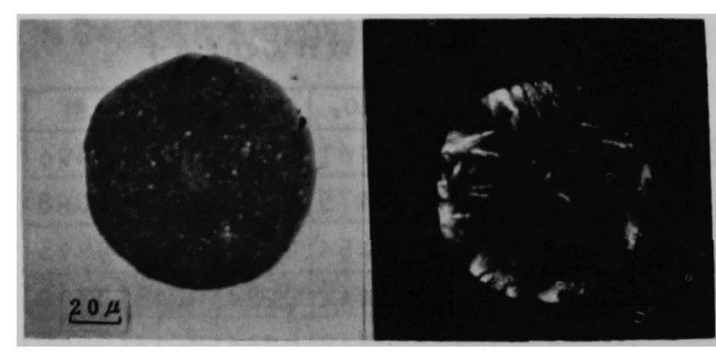

写真 1 介在物D - 1 の頿微鏡組變

a) 反射、b）避過

個々の介在物の平均の化学組成は、Bは rhodonite を晶出しているととからAK比べて $\mathrm{OaO}$ が低く $\mathrm{MnO}$ が高くなっているととが推定される。OとDはOr203

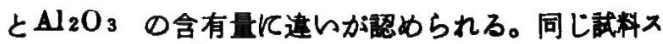
ラブて抽出分部した粗粒介在物 ( $>20 \mu)$ 化学分 析值社 $\mathrm{MnO}: 28 、 \mathrm{CaO}: 10 、 \mathrm{FeO}: 6 、 \mathrm{MgO}: 3$ 、 $\mathrm{Cr}_{2} \mathrm{O}_{3}: 7 、 \mathrm{Al}_{2} \mathrm{O}_{3}: 9 、 \mathrm{BiO}_{2}: 37$ のあり、Bま 上びのタイブの介在物が多く、AとDが少量てあるて とが推定され、上述の顕微钼繁結果に上く対応する ととがかかった。

1) M.Basaki , T.Takahari and H.Hamada : Trans ISIJ ( $\left.\begin{array}{llll}1 & 9 & 6 & 8\end{array}\right)$, No. 4

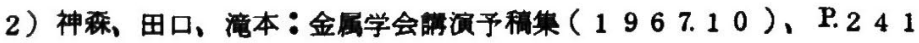




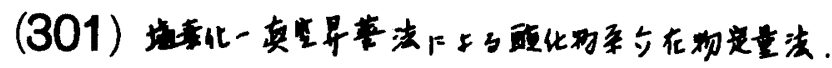

1. 蛇

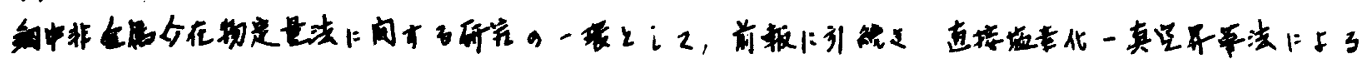

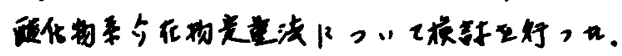

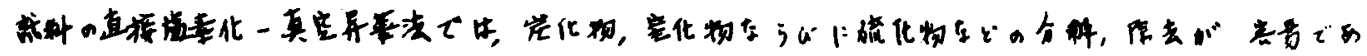

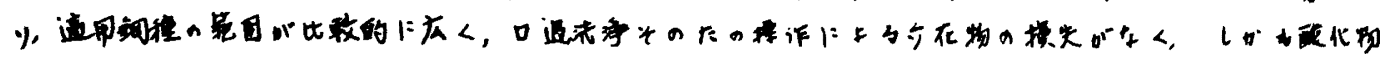

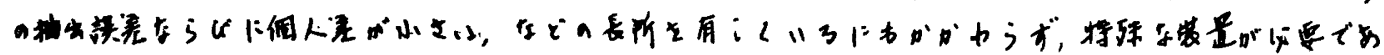

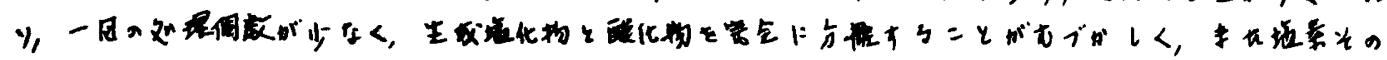

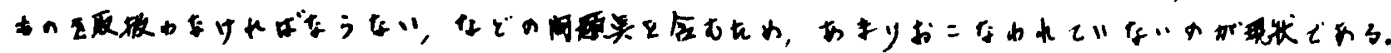

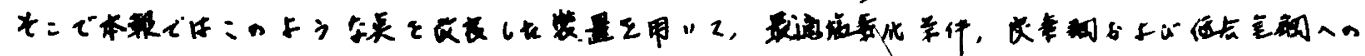

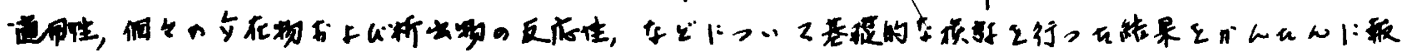
教了。

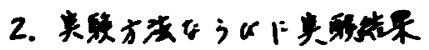

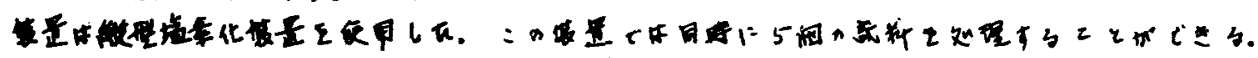

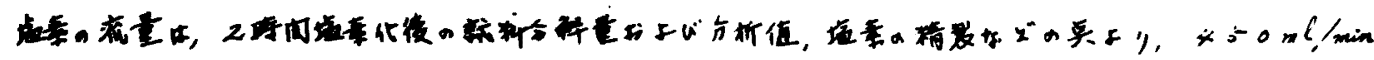

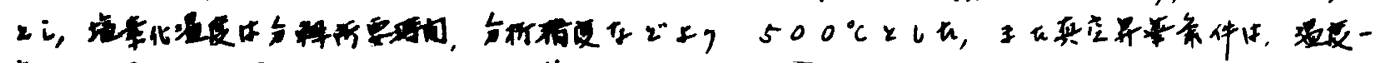

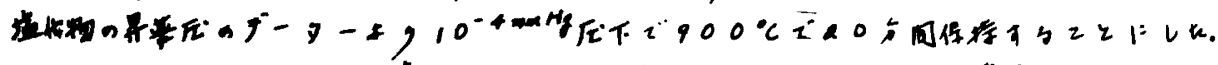

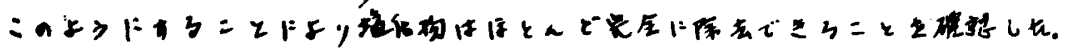

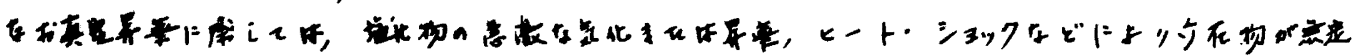

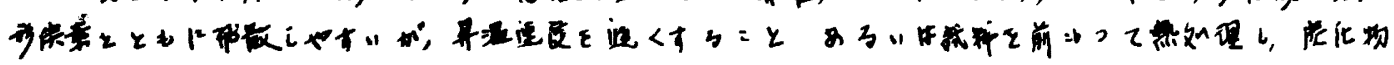

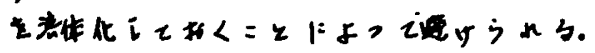

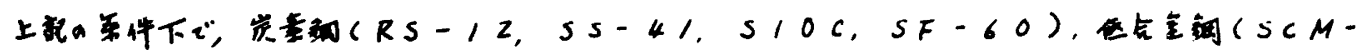

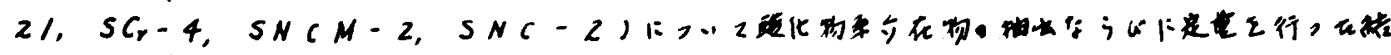

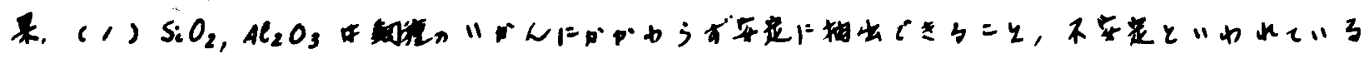

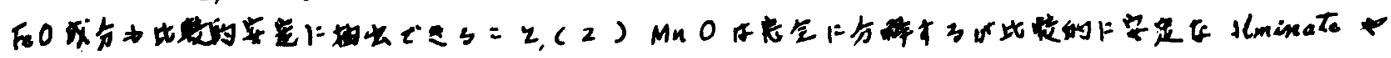

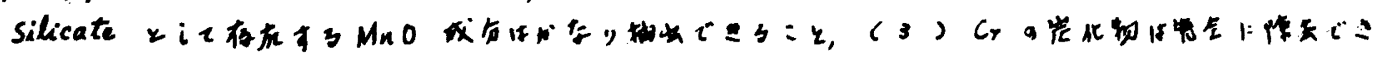

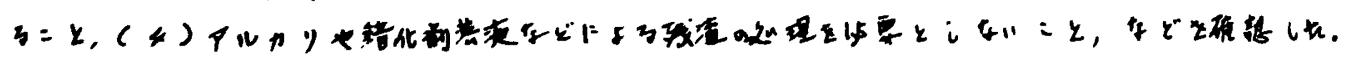

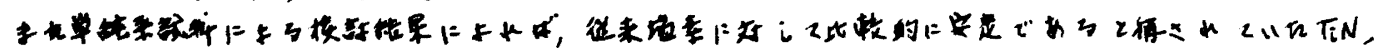

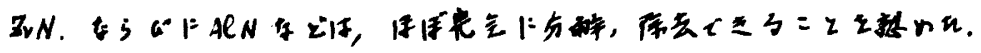

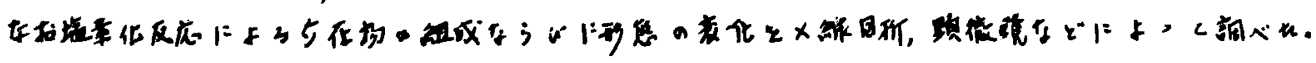


1 緒 言

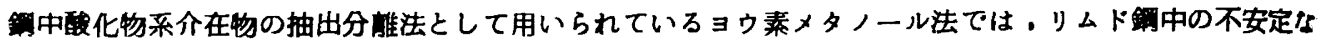
（Mn，Fe）Ｏの抽出事は著しく低い，乙の原因として，ヨウ素とメタノールの反応生成物によるととが推

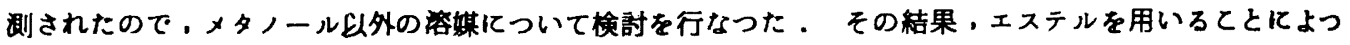

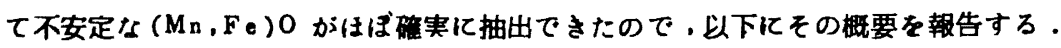

\section{2 実 铪}

(1) 供詰材

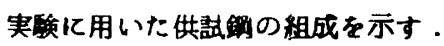

\begin{tabular}{|c|c|c|c|c|c|}
\hline & & & & & \\
\hline C & $\mathrm{S}_{\mathrm{i}}$ & $\mathrm{Mn}$ & $\mathbf{P}$ & & 0 \\
\hline & $<0,0$ & 0.36 & 0.016 & 0.02 & 0,02 \\
\hline
\end{tabular}

(2) 签

ヨウ秦の洕媒としてアルコール（メタノール，エタノール）ならびにエステル（醋酸メチル，醋酸エチ ル。醋酸ブチル)を用いた。

(3) 媒の選択

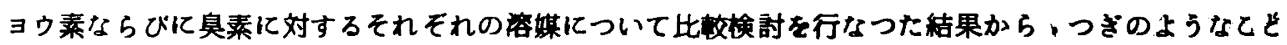

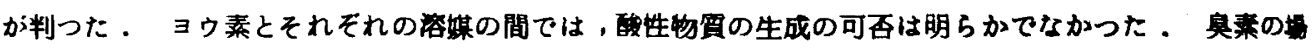

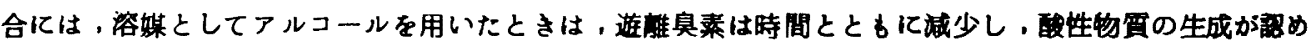
られたが、エステルを用いたときは検出されなかつた．とのととからヨウ秦の浴媒としてる，アルコー ルよりエステルの方が安定なととが推論された．エステルの中で醋酸エチル，醋酸ブチルはヨウ化矫の 浴解度か小さい難点があり，特に醋酸エチルは従来のメタノール添加基の倍以上る要するためて分析損作 の上から不通当であると考えられた .

3 実医結果

従来より用いられているョウ素メタノール法と，ヨウ素醋酸メチルならびにヨウ素醋酸ブチルを用いて， リムド鍮中酸化物系介在物の定量を行なつた。をその結果、ヨウ秦醋酸メチルとヨウ素醋酸ブチルの間には

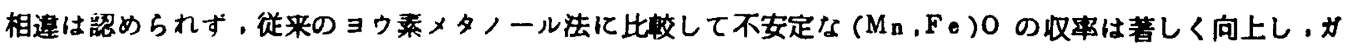
ス分析によろ酸素分析值とも良く一玫した值を示した。ままた試料分解後の提拌暗間は $1 \sim 3$ 時間の間では 分析值には殆んど相迺は認められな かつた.

以上の検討結果より・リムド侖中帔 化物系介在物定悬法としてヨウ秦醋 酸メチル法を用いるととにし、分襍 表 2 抽出残さ分析結果 (x)

\begin{tabular}{|c|c|c|c|c|c|c|}
\hline \multirow{2}{*}{ 抽出方法 } & \multirow{2}{*}{$\begin{array}{ll}\text { 分 } & \text { 解 } \\
\text { 条 } & \text { 件 }\end{array}$} & \multicolumn{4}{|c|}{ 残さ分析值（鲌中\%） } & \multirow{2}{*}{$\begin{array}{l}\text { 介在物 } \\
(\text { (क) }\end{array}$} \\
\hline & & $\mathrm{SiO}_{2}$ & $\mathrm{~S}_{2} \mathrm{O}_{8}$ & $\mathrm{MnO}$ & $\mathrm{FeO}$ & \\
\hline ヨウ素メタノール法 & $60 \mathrm{c} \times 1 \mathrm{~b}$ & 0.002 & 0.002 & 0,042 & 0.010 & 0.014 \\
\hline ヨウ焉醌酸メチル法 & $58 c \times 15 b$ & 0,002 & 0,002 & 0.112 & 0.015 & 0.031 \\
\hline
\end{tabular}

条件としては $58 \mathrm{C}$ で試料を分解し

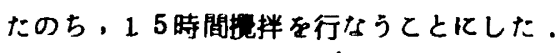

4 結 言

リムド銅中酸化物系介在物の抽出にヨウ录醋酸メチル法を用いるととにより，従来のヨウ素メタノール法 よりも不安定な $\left(\mathrm{Mn}_{\mathrm{n}}\right.$ ，Fe $) 0$ の収率が著しく向上した。 


\section{(303）鋼中のニオブの態别定量}

トピ一工業(株) 技術部若松茂雄

鈿中のNbの形熊に阅して枌討し太結果，主としてNb処理高張力䤧中のNbは大部分が岩空

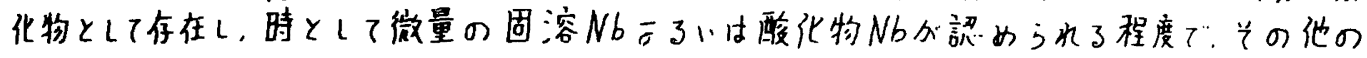

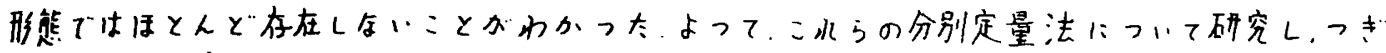
の㧹作法を磪立した。

1.Nb化合物の分離法

1.1 泠 $\mathrm{HCl}$ 法

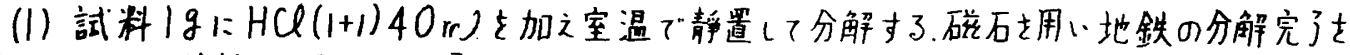

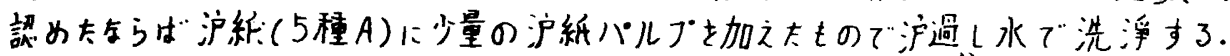

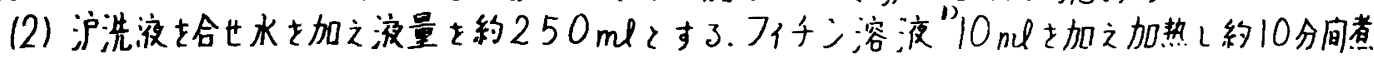

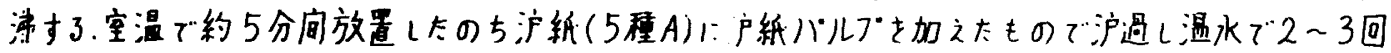
洗弾する.

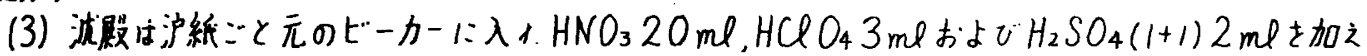

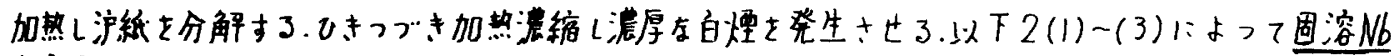
七定量する。

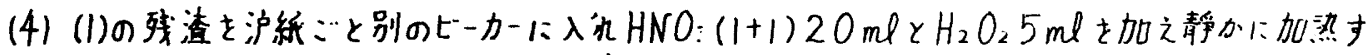

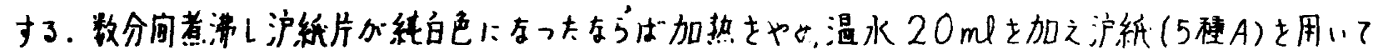
沪逐L温水7゙2-3回洗淨す了.

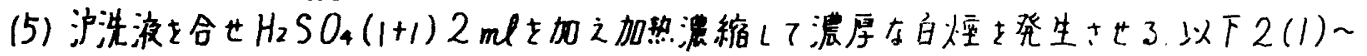
(3)によって岸窑化 $\mathrm{Nb}$ を定量す3.

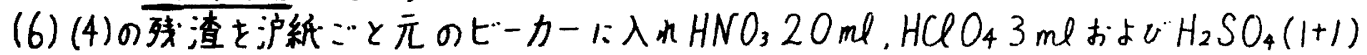

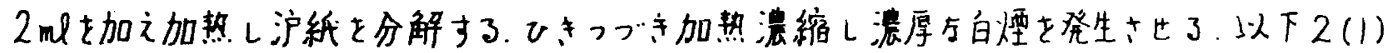
一(3)によって酸化物Nbを定量?了.

\section{$1.2 I \div$ \タ) -ル法}

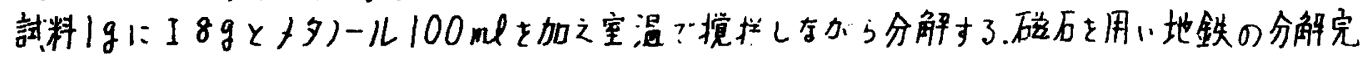

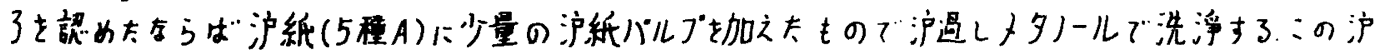

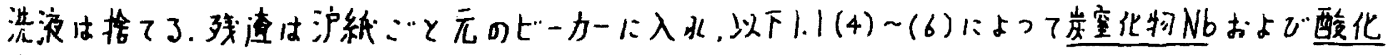
物N 6 t定量す了。

2. Nbの吸业光度定量方流

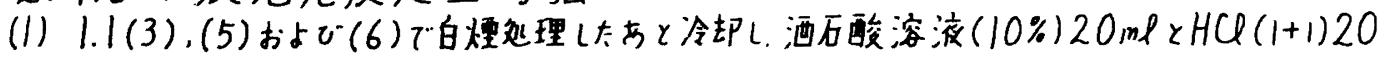

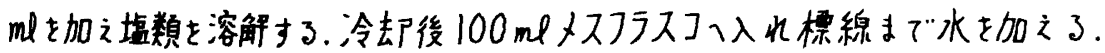

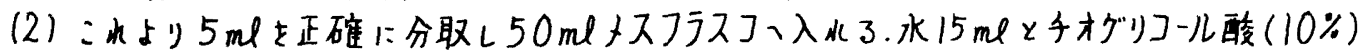

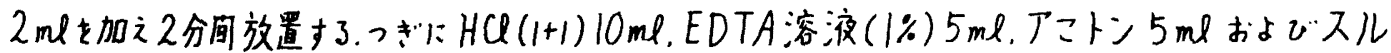

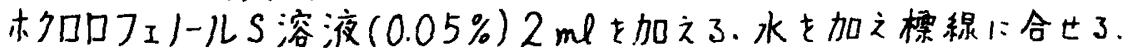

(3) $60 \sim 70^{\circ} \mathrm{C} 7$ 约5分间加温し太の5。波長650 m

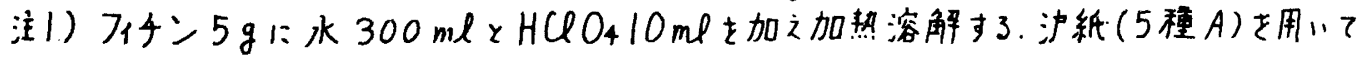

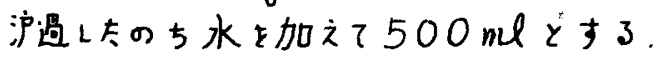


S 648

（304）鋼中のチ夕ンの態别定量

トピー工業(株)技術部若松茂雄

鈿中の固溶Ti，炭化物Ti，空化物T，および酸化物Tiの分别定量法を研究し、下記の操作法を䂭立し 太.

1. Ti 化合物の今離法

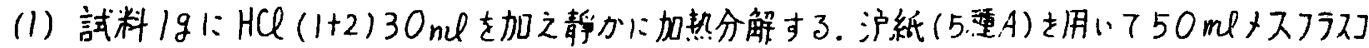

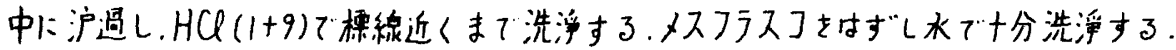

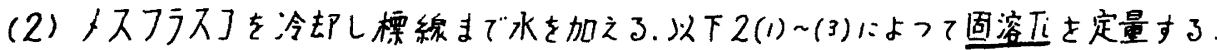

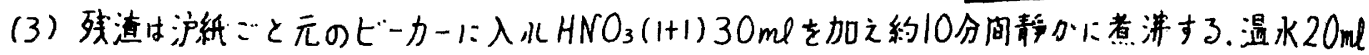

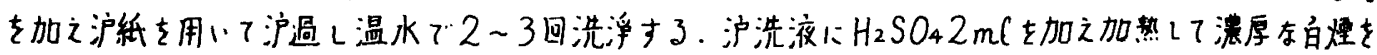

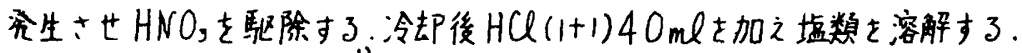

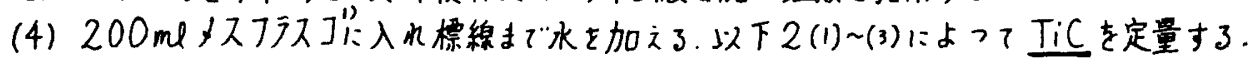

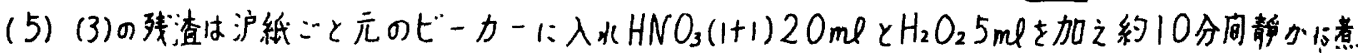

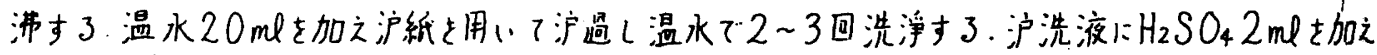

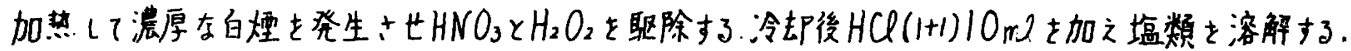

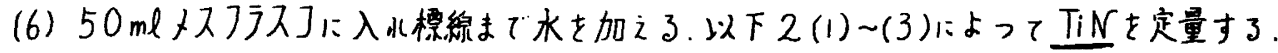

(7) (5)の残渣は沪紙ごと元のビーカーに入《 $\mathrm{HNO}_{3} 4 \mathrm{Oml}_{\text {. } \mathrm{HClO}} 3 \mathrm{ml}$ および $\mathrm{H}_{2} \mathrm{SO}_{4} 2 \mathrm{ml}$ 切

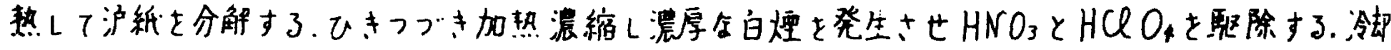
後 HCl (1+1) $10 \mathrm{ml}$ を加之塭類を溶角する。

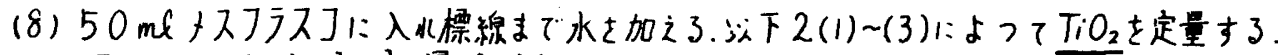

2. Ti 0吸光光度定量方法

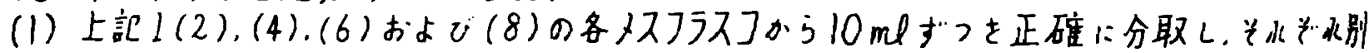

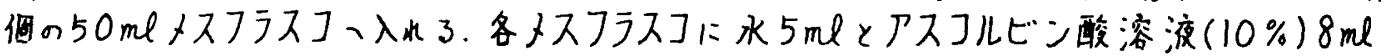

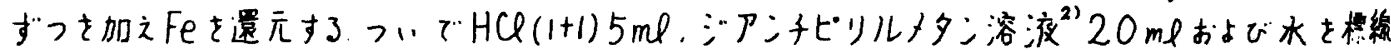
まで加之们を呈色させ了。

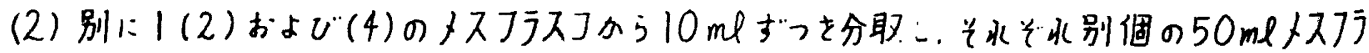

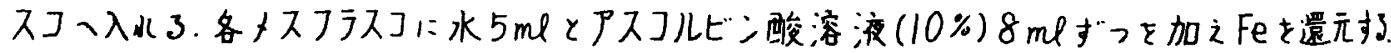

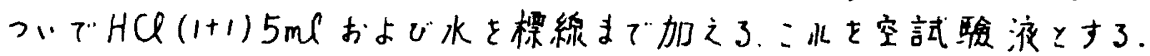

(3) 約20分後 2(2)の空試嬐液を州照とし72(1)の星色液の波長385 m

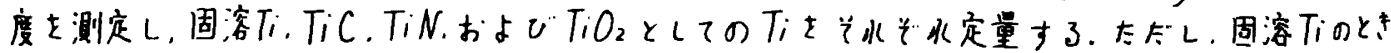

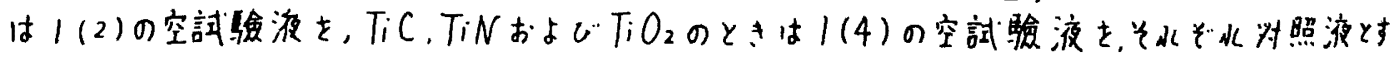
3 .

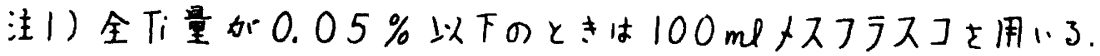

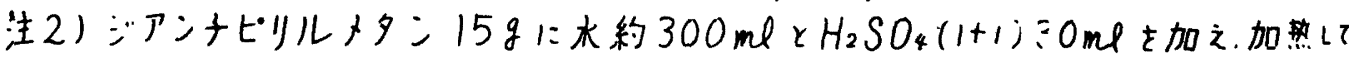

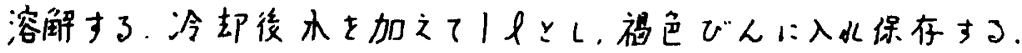

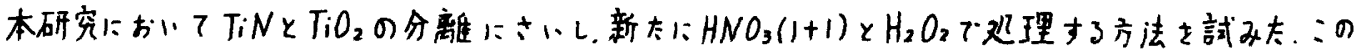

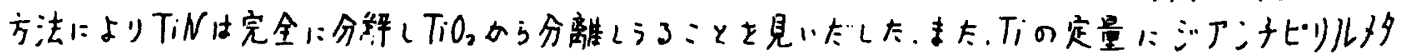
法を应用する:とによ简易迅速に微量のTiの定量が可能となった。 